\title{
Mateusz Grzesiak
}

\section{Wykorzystanie serwisu YouTube w kształtowaniu marki osobistej - wyniki badań}

\section{Kod JEL: M3}

Słowa kluczowe: marka osobista, młode pokolenie, kanał YouTube

Streszczenie. Kształtowanie marki osobistej przez przedstawicieli młodego pokolenia w coraz szerszym zakresie odbywa się dzięki tzw. nowym technologiom informacyjno-komunikacyjnym. Założono, że kanał YouTube jest jednym z najskuteczniejszych narzędzi kształtowania marki osobistej wśród przedstawicieli młodego pokolenia. W artykule przyjęto następujące cele: scharakteryzowanie kanału YouTube jako narzędzia pozwalającego na kształtowanie marki osobistej, zidentyfikowanie rozpoznawalności terminu „marka osobista” wśród młodego pokolenia, zidentyfikowanie świadomości dotyczącej możliwości wykorzystywania serwisu YouTube w kształtowaniu marki osobistej oraz wskazanie najlepszych praktyk w badanym zakresie.

\section{Wprowadzenie}

Zjawisko personal branding oznacza tworzenie marki osobistej przez celowe i świadome zarządzanie swoim wizerunkiem. Jest to zagadnienie zyskujące coraz większą popularność i stanowiące ważny problem naukowy, zwłaszcza w kontekście rozwoju nowych technologii informacyjno-komunikacyjnych. Dla reprezentantów młodego pokolenia wykorzystywanie nowych technologii stało się powszechne w życiu prywatnym i zawodowym. Jak wynika z badań przeprowadzonych przez agencję Think Kong, już 2,3 mln młodych odbiorców ser- 
wisu YouTube w Polsce w ogóle nie ogląda telewizji (YouTube w Polsce..., 2017). Oznacza to narodziny istotnego narzędzia do kreowania marki osobistej.

W artykule przyjęto następujące cele: scharakteryzowanie kanał YouTube jako narzędzia pozwalającego na kształtowanie marki osobistej, zidentyfikowanie rozpoznawalności terminu „marka osobista” wśród młodego pokolenia, zidentyfikowanie świadomości dotyczącej możliwości wykorzystywania serwisu YouTube w kształtowaniu marki osobistej oraz wskazanie najlepszych praktyk w badanym zakresie.

Dla osiągnięcia celów artykułu wykorzystano metodę krytycznej analizy literatury przedmiotu oraz przedstawiono wyniki badań bezpośrednich i przykłady wykorzystywania serwisu w celu kształtowania marki osobistej. Przyjęto zatem podejście ilościowe (badania bezpośrednie) i jakościowe (wskazanie na konkretne praktyki działań). Wyniki przedstawionych badań wskazują na wysoką skuteczność kanału YouTube w kształtowaniu marki osobistej.

$\mathrm{W}$ artykule wyodrębniono pięć części oraz podsumowanie. Dwie pierwsze mają charakter deskryptywny. Przedstawiono w nich kategorie badawcze podjęte $\mathrm{w}$ artykule. $\mathrm{W}$ następnych dwóch przedstawiono wyniki przeprowadzonych badań ilościowych dotyczących znajomości terminu „marka osobista” oraz świadomości młodego pokolenia dotyczącej możliwości wykorzystywania serwisu You Tube w celu jej kształtowania. W przedostatniej części przybliżono praktyki działań w zakresie wykorzystywania serwisu w celu kształtowania marki osobistej. Tak skonstruowana struktura artykułu pozwoliła na osiągnięcie zamierzonych celów.

\section{Marka osobista - charakterystyka pojęcia}

Dopiero internet, a następnie rozwój mediów społecznościowych wpłynęły na wielką popularność zjawiska personal brandingu, przez łatwość tworzenia i rozpowszechniania wirtualnej osoby, jak również wykorzystania jej do promocji i sprzedaży produktów i usług (Schawbel, 2014).

Pierwszym, który wskazał na istnienie zjawiska personal brandingu był Napoleon Hill (2013). Jego książka Myśl i bogać się wpłynęła na dostrzeżenie łączności między wzrostem przychodów a odpowiednim prezentowaniem produktów przez znaną osobę. Pojęcie ,marka osobista” spopularyzował Tom Peters (2003), amerykański pisarz i praktyk w dziedzinie zarządzania.

W drugiej dekadzie XXI wieku pojęcie „marki osobistej” wiąże się przede wszystkim z korzyściami wynikającymi ze stosowania narzędzi, dzięki którym każdy może stać się autorem i nadawcą swoich treści (Rampersad, 2008). Gwałtowny wzrost popularności treści wideo, zwłaszcza wśród osób młodych - 
przedstawicieli pokoleń $\mathrm{Y}$ i Z, rozwój smartTV ${ }^{1}$ czy powszechna dostępność i popularność serwisów społecznościowych, takich jak Facebook czy YouTube sprawiają, że nie tylko trudno jest budować własną markę z pominięciem tworzenia treści wideo, ale najprawdopodobniej jest to już obecnie niemożliwe (Poczęsna, 2014). Pokolenie $Z$ wyróżnia fakt oswojenia technologii - dla nich są one czymś zwyczajnym i codziennym - towarzyszyły im bowiem w życiu od urodzenia (Stopczyński, 2016, s. 206). Są do życia nastawieni w sposób realistyczny i materialistyczny, a zarazem bywają twórczy i ambitni. Chcą mieć wszystko i osiągać to natychmiast (Bilińska-Reformat, Stefańska, 2016, s. 129130).

\section{Serwis YouTube jako narzędzie pozwalające na ksztaltowanie marki osobistej}

Serwis YouTube jest jednym z najważniejszych filarów współczesnej kultury i metakultury. Wśród licznych funkcji odgrywa m.in. rolę narzędzia edukacyjnego, źródła informacji oraz promocji, stanowi bardzo ważne narzędzie oddziaływania marketingowego przez umożliwienie m.in. kreowania marki oraz angażowanie użytkowników.

Wśród użytkowników internetu na świecie, ponad miliard osób ogląda serwis YouTube. Regularnie zwiększa się liczba korzystających z tego kanału ( $40 \%$ dziennego wzrostu liczby oglądających osób w skali roku), ale także wydłuża się czas oglądania zawartości serwisie. W 2015 roku liczba godzin spędzonych przez widzów przed monitorami wyświetlającymi filmy na YouTube wzrosła o 60\% w porównaniu z rokiem 2014.

\section{Rozpoznawalność terminu „marka osobista” wśród przedstawicieli młodego pokolenia - wyniki badań polskich i amerykańskich użytkowników serwisu}

Celem badań prowadzonych przez autora było zidentyfikowanie stopnia wykorzystywania serwisu YouTube przez polskich i amerykańskich użytkowników do kreowania marki własnej. Dla osiągnięcia założonych celów wykorzystano metodę krytycznej analizy literatury przedmiotu oraz wyniki badań. Najpierw zrealizowano eksploracyjne badanie jakościowe (studia przypadków), a następnie badanie ilościowe.

Badania przeprowadzono w 2016 roku na grupie użytkowników w wieku 18-34 lata. Kwestionariusz ankiety - autorskie narzędzie pomiarowe - zaprogramowano na platformie Qualtrics.

\footnotetext{
${ }^{1}$ Już w pierwszym roku istotnej popularności rozwiązań smartTV odbiorcy tego typu rozwiązań stanowili liczniejszą grupę od klientów dużych operatorów kablowych (Wierzbowska, 2013, s. 216).
} 
Wyniki badań wskazują na różnice w rozpoznawalności terminu „marka osobista" wśród respondentów z Polski i Stanów Zjednoczonych. W Polsce termin rozpoznaje $45 \%$ ankietowanych, w Stanach Zjednoczonych 55\% - jest ich o $10 \%$ więcej.

52\% badanych Polaków i 67\% ze Stanów Zjednoczonych spotkało się $\mathrm{z}$ definicją „marka osobista” zgodnie z treścią przedstawioną przez autora niniejszego artykułu. Ponadto niemal $25 \%$ całej ankietowanych zadeklarowała budowanie marki osobistej zgodnie z zaprezentowaną definicją.

Mniej niż jedna trzecia badanych w obu krajach nie słyszała nigdy o terminie personal branding, a znaczący odsetek odpowiedział: „trudno powiedzieć" (19\% w USA, 27\% w Polsce). Można zatem stwierdzić, że tematyka ta zaczyna się pojawiać w ich życiu, przez co nie potrafią zadeklarować ani jej znajomości, ani definitywnie stwierdzić, że jej nie znają.

Dla części badanych „marka osobista” jest to wizerunek w oczach innych, także w obszarze biznesu i pracy zawodowej. Inni respondenci odpowiedzieli, że markę osobistą tworzą przede wszystkim znane osoby, takie jak celebryci, korzystając przy tym z ekspertów od public relations.

\section{Możliwości wykorzystywania serwisu YouTube w ksztaltowaniu marki osobistej - wyniki badań}

Kolejnym problemem poruszanym w badaniach było określenie świadomości użytkowników w zakresie możliwości kształtowania marki własnej z wykorzystaniem serwisu. Wielu respondentów badania sięga po aktywność, której celem jest budowa osobistej marki, jednocześnie nie mając świadomości, że korzystają z działań dotyczących tego zjawiska.

Z przeprowadzonych badań wynika, że $40 \%$ ankietowanych z Polski i $24 \%$ ze Stanów Zjednoczonych pracuje na rzecz swojej marki osobistej bez świadomości podejmowanych przez siebie działań. Dużo większa liczba osób w Stanach Zjednoczonych niż w Polsce wie, jak świadomie budować markę osobistą. Polacy działają bardziej nieświadomie, przez co nie zdają sobie sprawy z tego, że pracują na swoją markę osobistą.

Respondenci wykorzystujący serwis YouTube do budowy marki osobistej najczęściej nagrywają i publikują na swoich kanałach materiały wideo. 20\% respondentów w obu krajach deklaruje oglądanie już opublikowanych filmów, zbieranie inspiracji i uczenie się.

W obu badanych krajach zwracano uwagę na inne zalety serwis YouTube. W przypadku Polaków są nimi: duży zasięg (27\%) i łatwość dostępu do interesujących treści (14\%). Amerykanie wskazywali na możliwość prezentacji siebie, co pozwala świadomie i celowo budować oczekiwany wizerunek (21\%). Ponadto wymieniano duży zasięg serwisu (16\%) oraz wideo, jako atrakcyjny, nowoczesny i angażujący sposób na komunikację z innymi (16\%). 
W obu krajach ponad $40 \%$ respondentów wskazało na serwis YouTube jako najsilniejsze narzędzie wpływające na sferę poznawania nowych ludzi i ich życie towarzyskie. Wielu respondentów wskazuje na YouTube jako najlepsze medium do osiągnięcia sukcesu finansowego (55\% w Polsce, 39\% w USA), sukcesu w szkole, na uczelni czy w życiu zawodowym (ok. 30\% wszystkich respondentów).

Mocne strony serwisu YouTube to - w odpowiedziach respondentów z obu krajów - obszary związane z sukcesem finansowym i zawodowym. Ponad $80 \%$ badanych w obu krajach zdaje sobie sprawę z możliwości osiągania dochodów za pośrednictwem YouTube, a więcej niż jedna czwarta wszystkich respondentów zgadza się ze stwierdzeniami, że działanie w tym serwisie może stanowić główne źródło dochodu oraz, że można zarobić w nim duże pieniądze.

Znaczny odsetek młodych ludzi potwierdza stwierdzenie, że YouTube jest jednym z najskuteczniejszych narzędzi budowania przez nich personal brandingu (55\% respondentów w USA, 65\% w Polsce).

W pytaniu o porównanie stosunku do mediów tradycyjnych i nowoczesnych, znaczny odsetek respondentów z Polski deklaruje większe zaufanie do YouTube (54\%) i fakt większego liczenia się ze zdaniem znanych YouTuberów niż telewizyjnych sław (45\%). Z kolei w obu krajach, YouTube stanowi najważniejsze źródło odbioru treści przekazywanych przez gwiazdy mediów społecznościowych.

Wyniki badań wskazują na duży potencjał wykorzystania serwisu YouTube $\mathrm{w}$ celu kształtowania personal brandingu w przyszłości. W obu krajach celem korzystania z serwisu jest korzystne postrzeganie przez innych (40\% Amerykanie, 16\% Polacy), sukces zawodowy (23\% Amerykanów, 15\% Polaków), własna satysfakcja (13\% w Polsce, 1\% Amerykanów), osiąganie celów i odnoszenie sukcesów - $10 \%$ respondentów w każdym kraju.

\section{Wykorzystanie kanału YouTube na rzecz kształtowania marki osobistej - wybrane praktyki działań}

Dzięki przeprowadzonym badaniom oraz analizie nowoczesnego i popularnego wśród młodych ludzi narzędzia, jakim jest serwis YouTube, można zidentyfikować konkretne cechy działania i odpowiadające im aktywności, pozwalające z sukcesem zbudować osobistą markę. Scharakteryzowane je w tabeli 1.

Kształtowanie marki osobistej z wykorzystaniem serwisu YouTube jest procesem wymagającym strategicznego podejścia. Specjaliści od marketingu w kampaniach reklamowych chętnie korzystają z udziału rozpoznawalnych osób, których poparcie może przysłużyć się marce. Przykładem z może być Łukasz Jakóbiak współpracujący z marką Opel (Poznaj Opla ..., 2017). 
Działania umożliwiające skuteczne budowanie marki za pośrednictwem serwisu You Tube

\begin{tabular}{|c|c|c|}
\hline Cecha działania & Charakterystyka działania & Przykłady \\
\hline Interaktywność & $\begin{array}{l}\text { regularny kontakt z oglądającymi kanał YouTube } \\
\text { przez śledzenie zamieszczanych przez nich komenta- } \\
\text { rzy i aktywne reagowanie na zgłaszane potrzeby, } \\
\text { krytykę czy pytania }\end{array}$ & $\begin{array}{l}\text { Ewa Chodakowska } \\
\text { systematycznie } \\
\text { wchodzi w interak- } \\
\text { cje ze swoimi fan- } \\
\text { kami }\end{array}$ \\
\hline $\begin{array}{l}\text { Współpraca } \\
\text { z innymi You- } \\
\text { Tuberami }\end{array}$ & $\begin{array}{l}\text { łączenie sił przez tworzenie wspólnego wideokonten- } \\
\text { tu, udział w tych samych akcjach promocyjnych } \\
\text { w celu zwiększenia zasięgu swoich treści i popular- } \\
\text { ności kanału poprzez uzyskanie uwagi subskryben- } \\
\text { tów osoby zaproszonej do współpracy }\end{array}$ & $\begin{array}{l}\text { Abstrachuje wystę- } \\
\text { pujący gościnnie } \\
\text { u Szparagów }\end{array}$ \\
\hline $\begin{array}{l}\text { Stosowanie } \\
\text { przewidywal- } \\
\text { nego formatu }\end{array}$ & $\begin{array}{l}\text { umieszczenie informacji w jednym z rozpoznawal- } \\
\text { nych formatów kanału, aby widz bez problemu mógł } \\
\text { podjąć decyzję o jego subskrypcji oraz regularnego } \\
\text { oglądania }\end{array}$ & $\begin{array}{l}\text { Łukasz Jakóbiak } \\
\text { prowadzi kanał } \\
20 \mathrm{~m} 2\end{array}$ \\
\hline $\begin{array}{l}\text { Konsekwencja } \\
\text { - regularność } \\
\text { podejmowa- } \\
\text { nych aktywno- } \\
\text { ści }\end{array}$ & $\begin{array}{l}\text { stałe zamieszczanie świeżych materiałów w tej samej } \\
\text { porze ustalonego przez siebie cyklu, np. raz w tygo- } \\
\text { dniu w piątek o godz. } 20.00\end{array}$ & $\begin{array}{l}\text { Cezary Pazura } \\
\text { publikuje swoje } \\
\text { filmy raz w tygo- } \\
\text { dniu w środę }\end{array}$ \\
\hline $\begin{array}{l}\text { Niepowtarzalna } \\
\text { osobowość }\end{array}$ & $\begin{array}{l}\text { stworzenie i konsekwentne wykorzystywanie wyjąt- } \\
\text { kowej osobowości, aby nie tylko można ją było } \\
\text { łatwo zapamiętać, ale również by odróżniała się od } \\
\text { innych autorów, z podobnymi kanałami na YouTube; } \\
\text { w kreacji oryginalnej osobowości pomaga charakte- } \\
\text { rystyczny ubiór, rozpoznawalny język przekazu, } \\
\text { zachowanie wraz z typowymi dla autora elementami } \\
\text { mowy ciała oraz rodzaj komunikacji }\end{array}$ & $\begin{array}{l}\text { Sylwester Wardęga } \\
\text { często przebiera się } \\
\text { w swoich produk- } \\
\text { cjach filmowych }\end{array}$ \\
\hline $\begin{array}{l}\text { Multikanało- } \\
\text { wość }\end{array}$ & $\begin{array}{l}\text { korzystanie z wielu serwisów społecznościowych } \\
\text { (Facebook, Instagram, Snapchat, LinkedIn, itd.) } \\
\text { w celu zamieszczania odnośników do swojego kana- } \\
\text { łu YouTube, dzięki czemu następuje zwiększenie } \\
\text { zasięgu komunikacji oraz pozyskanie uwagi użyt- } \\
\text { kowników poza kanałem YouTube }\end{array}$ & $\begin{array}{l}\text { Abstrachuje prowa- } \\
\text { dzą kanał na Face- } \\
\text { book, Instagram, } \\
\text { YouTube, Snapchat }\end{array}$ \\
\hline $\begin{array}{l}\text { Precyzyjne } \\
\text { określanie } \\
\text { grupy docelo- } \\
\text { wej }\end{array}$ & $\begin{array}{l}\text { określenie grupy odbiorców pod względem psycho- } \\
\text { grafii i demografii, a także tak tworzeni foryę i treści } \\
\text { komunikatu, by maksymalnie odpowiadał potrzebom } \\
\text { konkretnej grupy }\end{array}$ & $\begin{array}{l}\text { Wapniak podjął } \\
\text { działania rebrandin- } \\
\text { gowe zmieniając } \\
\text { grupę docelową }\end{array}$ \\
\hline
\end{tabular}


Wykorzystanie serwisu YouTube w ksztaltowaniu marki osobistej...

\begin{tabular}{|l|l|l|}
\hline $\begin{array}{l}\text { Współpraca } \\
\text { z markami }\end{array}$ & $\begin{array}{l}\text { zamieszczanie reklam marek czy product placement } \\
\text { na swoim kanale i recenzowanie produktów dostar- } \\
\text { czanych przez producentów, dzięki czemu wzrastają } \\
\text { przychody kanału oraz zwiększa się jego zasięg } \\
\text { i możliwość dotarcia do nowych odbiorców }\end{array}$ & $\begin{array}{l}\text { Łukasz Jakóbiak } \\
\text { współpracujący } \\
\text { z marką Opel }\end{array}$ \\
\hline $\begin{array}{l}\text { Sprzedaż pro- } \\
\text { duktów }\end{array}$ & $\begin{array}{l}\text { dzięki popularności kanału sprzedaż własnych pro- } \\
\text { duktów reklamowych stanowiących nośniki reklamy } \\
\text { kanału }\end{array}$ & $\begin{array}{l}\text { Jaś Dąbrowski } \\
\text { sprzedaje odzież } \\
\text { w ramach swojej } \\
\text { marki JDabrowsky } \\
\text { Wear }\end{array}$ \\
\hline $\begin{array}{l}\text { Publikacje } \\
\text { medialne }\end{array}$ & $\begin{array}{l}\text { sięganie po działania media relations w celu poja- } \\
\text { wienia się w mediach informacji o kanale }\end{array}$ & $\begin{array}{l}\text { Jaś Dąbrowski } \\
\text { prowadzi audycje } \\
\text { w Programie } \\
\text { Czwartym Polskie- } \\
\text { go Radia }\end{array}$ \\
\hline $\begin{array}{l}\text { Publikacje } \\
\text { książkowe }\end{array}$ & $\begin{array}{l}\text { opublikowanie treści z kanału w książce, korzystając } \\
\text { zię do dodatkowej promocji, albo we własnym zakre- } \\
\text { sie; książka zwiększa prestiż kanału, stanowiąc } \\
\text { bardzo istotne wzmocnienie jakości marki osobistej } \\
\text { w oczach widzów }\end{array}$ & $\begin{array}{l}\text { Ewa Grzelakowska- } \\
\text { Kostoglu: Red } \\
\text { Lipstick Monster } \\
\text { Tajniki Makijażu }\end{array}$ \\
\hline $\begin{array}{l}\text { Spotkania } \\
\text { z użytkowni- } \\
\text { kami }\end{array}$ & $\begin{array}{l}\text { udział w wydarzeniach, na których widzowie mogą } \\
\text { spotkać swoich ulubionych YouTuberów, co pozwa- } \\
\text { la na wzrost rozpoznawalności kanału }\end{array}$ & $\begin{array}{l}\text { Krzysztof Gonciarz } \\
\text { spotyka się z fanami }\end{array}$ \\
\hline
\end{tabular}

Żródło: opracowanie własne.

Aby utrzymać trend obecności w mediach, wielu YouTuberów decyduje się na publikację własnej książki. Ewa Grzelakowska-Kostoglu, znana na YouTube jako Red Lipstick Monster, wydała książkę dotyczącą tajników makijażu.

Ugruntowana marka pomaga w podjęciu działalności w nowej branży, promocję buduje się wówczas na podstawie rozpoznawalności nazwiska. Przykładem tego typu działań może być otwarcie przez Nergala salonu fryzjerskiego dla mężczyzn - Barberian Academy \& Barber Shop (Sosin, 2017).

Youtuberzy często upubliczniają produkcje, w których razem występują jest to tzw. crossowanie, prowadzące do zwiększenia bazy subskrybentów i zwiększa zasięgi oglądalności - np. Abstrachuje i Szparagi.

Ewa Chodakowska utrzymuje stały kontakt ze swoimi fankami, zwracając się do nich per „babeczki”, „kocurki” czy „fajterki” i często wchodzi w bezpośrednie interakcje w komentarzach w swoich mediach społecznościowych.

Zdecydowana większość YouTuberów korzysta ze strategii multikanałowości, prowadząc działalność jednocześnie na kilku serwisach społecznościowych (najczęściej Facebook, YouTube, Instagram, Snapchat), np. Sylwester Wardęga. 
Jedną ze skutecznych praktyk jest także regularność podejmowanych aktywności i stosowanie przewidywalnego formatu. Cezary Pazura co środę umieszcza na swoim kanale YouTube podobnej długości filmy.

YouTuberzy sprzedają również swoje własne produkty. Do najpopularniejszych należy odzież (Abstrachuje, JDabrowsky).

\section{Podsumowanie}

Na podstawie zaprezentowanych wyników badań własnych oraz analizy aktywności czołowych YouTuberów można stwierdzić, że najlepszym sposobem budowania marki osobistej jest stała obecność i aktywność w mediach społecznościowych, czyli regularne zamieszczanie tekstów, zdjęć i filmów wideo (Matney, 2015). Badania ilościowe zrealizowane w Polsce i USA wskazują, że reprezentanci młodego pokolenia mają świadomość potencjału serwisu YouTube i zdają sobie sprawę z możliwości dotyczących kształtowania marki osobistej przy jego pomocy.

Z możliwości, jakie oferuje portal YouTube, korzysta 25-30\% wszystkich ankietowanych. YouTube zajmuje drugie miejsce w rankingu portali wykorzystywanych do budowania personal brandingu wśród polskich badanych, zaś dopiero szóste miejsce wśród ankietowanych ze Stanów Zjednoczonych (2. Instagram, 3. LinkedIn, 4. Twitter i 5. Snapchat).

W podobny sposób kształtują się proporcje w przypadku opinii na temat skuteczności portali społecznościowych wykorzystywanych do tworzenia marki osobistej. Na Facebook wskazało 56\% badanych Polaków i 32\% Amerykanów, natomiast $20 \%$ respondentów uznaje serwis YouTube za najskuteczniejszy $\mathrm{w}$ procesie kreowania personal brandingu.

Przeprowadzone badania wskazują, że nagrywanie i publikowanie filmów na YouTube stanowi główną aktywność na rzecz budowania marki osobistej. Niemała liczba ankietowanych, bo aż 19\% wskazuje na YouTube, jako główne źródło wiedzy i inspiracji. Do najważniejszych zalet serwisu w tym obszarze należy: globalny zasięg, możliwość prezentacji się z jak najlepszej strony i atrakcyjny sposób komunikacji, jakim jest materiał wideo.

W świetle przeprowadzonych badań, silna pozycja kanału YouTube, jako przestrzeni dającej szansę na zarabianie satysfakcjonujących i atrakcyjnych pieniędzy, wskazuje na dalszy wzrost znaczenia serwisu, jako narzędzia do budowania i kreowania marki osobistej wśród młodych ludzi.

Analiza jakościowa, pokazująca przykłady wykorzystywania serwisu YouTube, wskazuje również na bardzo duże możliwości serwisu YouTube w kształtowaniu marki osobistej. 


\section{Bibliografia}

Bilińska-Reformat, K., Stefańska, M. (2016). Young Consumer's Behaviours on Retail Market and Their Impact on Activities of Retail Chains. Business Excellence, 11 (October).

Hill, N. (2013). Myśl i bogać się. Warszawa: Wydawnictwo Studio Emka.

Matney, L. (11.04.2016). Snapchat reaches 6 billion daily videos views, tripling from 2 billion in May. Pobrano z: http://techcrunch.com/2015/11/09/snapchat-reaches-6-billion-dailyvideos-views-tripling-from-2-in-may.

Peters, T. (2003). Movers and shakers: The 100 most influential figures in modern business. Londyn: Basic Books.

Poczęsna, J. (2014). Personal branding - czyli jak zbudować markę osobista w sieci? Pobrano z: www.bankier.pl/wiadomosc/Personal-branding-czyli-jak-zbudowac-marke-osobista-w-sie ci-3027890.html (11.04.2016).

Poznaj Opla (1.05.2017). Pobrano z: www.opel.pl/poznaj-opla/o-oplu/opel-aktual-nosci/2015/ grudzien/adam-yourself.html.

Rampersad, H.K. (2008). A new blueprint for powerful and authentic personal branding. Performance Improvement, 6.

Schawbel, D. (2014). Personal Branding 2.0. Cztery kroki do zbudowania osobistej marki. Gliwice: Wydawnictwo OnePress.

Sosin, N. (1.05.2017). Wizyta u barbarzyńskiego golibrody. Nergal: dbanie o atrybuty męskości ma wplyw na to, co mamy wewnatrz. Pobrano z: http://weekend.gazeta.pl/weekend/ 1,152121,16856499,Wizyta_u_barbarzynskiego_golibrody_Nergal_Dbanie.html.

Stopczyński, B. (2006). Dywersyfikacja zachowań nabywców sklepów online w zależności od wieku klienta. W: M. Krajewska-Nieckarz, A. Piekarska, A. Sołtys (red.), W stronę różnorodności - nowe wyzwania w zarządzaniu organizacją i potencjałem społecznym. Przedsiębiorczość i Zarządzanie, XVII, (2/III).

Wierzbowska, T. (2013). Wideo i audio w sieci. W: J. Królewski, P. Sala (red.), E-marketing. Wspótczesne trendy. Pakiet startowy Warszawa: Wydawnictwo Naukowe PWN

YouTube w Polsce w 2014 roku. (13.08.2015). Pobrano z: www.brief. pl/artykul, 2330, youtube_w_polsce_w_2014_roku.html.

\section{Using Youtube Channel for Personal Brand Creation - Results of Research}

Keywords: personal brand, young generation, YouTube channel

Summary. The young generation representatives create their personal brand by greater use of the newest communication and information technologies. It is assumed in the paper that YouTube channel is one of the most effective tools used by to shape a personal brand by young people. There are following objectives of the paper: to characterize YouTube as a tool for shaping a personal brand, to identify the familiarity of the term 'personal brand' among young people, to identity awareness of YouTube's ability to shape a personal brand and to indicate best practices in the studied field.

Translated by Mateusz Grzesiak

\section{Cytowanie}

Grzesiak, M. (2017). Wykorzystanie serwisu YouTube w kształtowaniu marki osobistej - wyniki badań. Marketing i Zarzadzanie, 1 (47), 333-341. DOI: 10.18276/miz.2017.47-31. 